УДК 636.5.084

https://doi.org/10.32634/0869-8155-2021-354-11-12-20-23

Оригинальное исследование/Original research

Дежаткина С.В.,

Феоктистова Н.А.,

Панкратова Е.В.,

Проворова Н.А.,

Салмина Е.С.

ФГБОУ ВО «Ульяновский государственный аграрный университет имени П.А. Столыпина», 432017, г. Ульяновск, Бульвар Новый Венец, д. 1 E-mail:dsw1710@yandex.ru

Ключевые слова: кормовая добавка, цеолит, аминокислоты, индейка, живая масса, рацион

Для цитирования: Дежаткина С.В., Феоктистова Н.А., Панкратова Е.В., Проворова Н.А., Салмина Е.С. Биодобавки на основе модифицированного и обогащенного аминокислотами цеолита при выращивании молодняка индеек. Аграрная наука. 2021; 354 (11-12): 20-23.

https://doi.org/10.32634/0869-8155-2021-354-11-12-20-23

Конфликт интересов отсутствует

Svetlana V. Dezhatkina,

Natalya A. Feoktistova,

Elena V. Pankratova,

Natalya A. Provorova

Ekaterina S. Salmina

Ulyanovsk State Agrarian University named after P.A. Stolypin, 432017, Ulyanovsk, Novy Venets Boulevard,

Key words: feed additive, zeolite, amino acids, turkey, live weight, diet

For citation: Dezhatkina S.V., Feoktistova N.A. Pankratova E.V., Provorova N.A., Salmina E.S. Dietary supplements based on modified and enriched with amino acids zeolite in the cultivation of young turkeys. Agrarian Science. 2021; 354 (11-12): 20-23. (In Russ.)

https://doi.org/10.32634/0869-8155-2021-354-11-12-20-23

There is no conflict of interests

Биодобавки на основе модифицированного и обогащенного аминокислотами цеолита при выращивании молодняка индеек

\title{
PЕЗЮME
}

Актуальность. Современные кроссы индеек обладают генетически обусловленной высокой скоростью роста. Эти сельскохозяйственные птицы очень чувствительны даже к незначительным колебаниям в их рационе, восприимчивы к дефициту аминокислот, протеина, минеральных элементов и витаминов, что может способствовать снижению их продуктивности, развитию патологических процессов и заболеваний. Использование современных технологий и достижений науки позволило приготовить новый продукт - модифицированный цеолит. Этот природный минерал уже без примесей и микробов, с открытыми окошечками пор, обладающий высокой способностью к селективному обмену, получен разными способами активации цеолита в промышленных условиях. При этом ульяновские специалисты освоили технологию обогащения полезными веществами модифицированного цеолита.

Материал и методы. Целью работы стало изучение влияния на организм индеек и уровень их продуктивности добавки на основе модифицированного цеолита, обогащенного аминокислотами. Эксперимент организован в течение 60 дней на 250 индейках породы Hybrid Cread-mayker возраста 55-60 дней в условиях Ульяновской области. Контрольная группа получала основной рацион (OP), опытной группе дополнительно к ОР давали раз в сутки в утреннее кормление в смеси с комбикормом $5 \%$ добавки модифицированного цеолита, обогащенного аминокислотами.

Результаты. Включение в рацион индеек добавки на основе модифицированного цеолита, обогащенного аминокислотами, не оказывает отрицательного влияния на гематологические параметры их крови, все показатели соответствовали физиологической норме. За время опыта во 2-й группе получено живым весом больше птицы на 8,70\%, что составило 12296 кг, соответственно больше получено прибыли при реализации мяса индейки, общая выручка составила 133210 , а дополнительная прибыль - 27960 рублей, на 1 рубль затрат получено 2,41 рубля прибыли. Данные указывают на нормализацию минерального гомеостаза в организме индеек и лучшее усвоения питательных веществ кормового рациона.

\section{Dietary supplements based on modified and enriched with amino acids zeolite in the cultivation of young turkeys}

\section{ABSTRACT}

Relevance. Modern turkey crosses have a genetically determined high growth rate. These farm birds are very sensitive to even minor fluctuations in their diet, are susceptible to a deficiency of amino acids, protein, mineral elements and vitamins, which can contribute to a decrease in their productivity, the development of pathological processes and diseases. The use of modern technologies and scientific achievements has made it possible to prepare a new product - modified zeolite. This natural mineral is already free of impurities and microbes, with open pore windows, has a high ability to selectively exchange, and is obtained by various methods of activating zeolite in industrial conditions. At the same time, Ulyanovsk specialists have mastered the technology of enriching modified zeolite with useful substances.

Methods. The aim of the work was to study the effect on the body of turkeys and the level of their productivity of additives based on modified zeolite enriched with amino acids. The experiment was organized for 60 days on 250 turkeys of the breed Hybrid Cread-mayker aged 55-60 days in the conditions of the Ulyanovsk region. The control group received the main ration (MR), the experimental group was given once a day in addition to the MR in the morning feeding in a mixture with mixed feed $5 \%$ additives of modified zeolite enriched with amino acids.

Results. The inclusion of a supplement based on modified zeolite enriched with amino acids in the diet of turkeys does not have a negative effect on the hematological parameters of their blood, all indicators corresponded to the physiological norm. During the experiment in the 2nd group, the live weight of poultry was obtained larger by $8.70 \%$, which amounted to $12,296 \mathrm{~kg}$, respectively, more profit was obtained from the sale of turkey meat, total revenue was 133,210 , and additional profit was 27,960 rubles, 2.41 rubles of profit was received for 1 ruble of costs. The data indicate the normalization of mineral homeostasis in the body of turkeys and better absorption of nutrients in the feed diet.

Поступила: 14 сентября

После доработки: 22 сентября

Принята к публикации: 15 ноября
Received: 14 September

Revised: 22 September

Accepted: 15 November 


\section{Введение}

Продукция птицеводства является весьма привлекательной для российских потребителей, что связано с высокой экономичностью производства мяса птицы, которое обходится значительно дешевле, чем, например, производство говядины и свинины, и не требует большого расхода кормов, энергии и затрат рабочей силы [1, 12].

Современные проблемы и будущее птицеводства России тесно связаны с развитием науки. Научные учреждения призваны осуществлять разработку фундаментальных и прикладных проблем, при этом важнейшими направлениями работы отраслевой и вузовской науки являются развитие инновационной деятельности, апробация и внедрение научных достижений в практику. Значительное место занимают научные исследования в области кормовых добавок. Учеными Ульяновского государственного аграрного университета имени П.А. Столыпина разработана новая рецептура кормовых добавок на основе природных кремнийсодержащих минералов, обработанных инновационными технологиями $[2,11]$

Развитие птицеводства на промышленной основе влечет за собой ряд проблем: необходимость создания определенного микроклимата для птиц и обеспечения полноценного кормления. Помещения для птиц должны отвечать необходимым требованиям и соблюдать температурный, световой, влажностный режим, необходимоочищать воздух от вредных газов и пыли. Клеточное содержание способствует развитию клеточной усталости, гиподинамии, истерии, синдрома жирной печени у сельскохозяйственных птиц. Отмечают гипертрофию гребня, атрофию семенников, искривление киля грудной кости, кисты яичников и прочее. Все это отрицательно сказывается на физиологическом состоянии организма и продуктивности птиц $[3,4,10]$

В свою очередь рационы сельскохозяйственной птицы не всегда отвечают их потребностям. Часто имеется недостаток питательных веществ, минеральных элементов и витаминов. Использование химических добавок и премиксов не приводит к желаемому результату, не улучшает усвоение веществ кормового рациона. В результате происходит повышение затрат корма и снижение продуктивности птиц, при этом производитель получает продукцию низкого качества $[5,6]$. Развитие отрасли отечественного индейководства позволяет не только увеличить производство мяса птиц, но и расширить ассортимент отличной диетической продукции. В России доля индюшатины в валовом производстве мяса птиц в убойной массе составляет около 4\%. Важно учитывать, что современные кроссы индеек обладают генетически обусловленной высокой скоростью роста. Эти сельскохозяйственные птицы очень чувствительны даже к незначительным колебаниям в их рационе, восприимчивы к дефициту аминокислот, протеина, минеральных элементов и витаминов, что может способствовать снижению их продуктивности, развитию патологических процессов и заболеваний [7].

Одним из путей решения вышеуказанных проблем в индейководстве может стать применение кормовых добавок на основе модифицированных цеолитов, обогащенных аминокислотами, а также использование цеолитового подстила для напольного содержания птиц.

Природный цеолит (клиноптилолит) относится к кремнийсодержащей микропористой минеральной породе, является полезным ископаемым и принадлежит к группе водных алюмосиликатов. Состоит из анионной части - кремния и тетраэдра алюминия $(4: 1,8: 1)-$ и катионной части (катионов натрия $\mathrm{Na}^{+}$, кальция $\mathrm{Ca}^{++}$, цинка $\mathrm{Zn}^{++}$, магния $\mathrm{Mg}^{++}$, калия $\mathrm{K}^{+}$и других), находящейся в каналах кристаллической решетки. Природный цеолит содержит большое количество кремния (до $40 \%)$, он не только образует кристаллическую решетку, но и в виде катионов находится в ее каналах. При поступлении цеолита в организм человека, животных и птиц $\mathrm{SiO}_{4}$ превращается в $\mathrm{SiO}_{2}$, который отличается высокой биологической усвояемостью. Как минеральная губка, клиноптилолит может поглощать воду до $40 \%$ и более и обратно ее отдавать при нагреве, не изменяя при этом своей структуры. Он обладает способностью увеличивать адсорбционную поверхность в кишечнике в 300 раз и как адсорбент связывает растворенные и газообразные вещества. Благодаря своим свойствам ионообменника, катализатора, молекулярного сита, адсорбента цеолит является регулятором минерального обмена, нейтрализует токсины, яды, вредные газы и радионуклиды, уничтожает бактерии, вирусы и грибы. В целом улучшает переваримость питательных веществ рациона и оказывает положительное влияние на продуктивность и физиологическое состояние организма $[8,9]$.

В противоположность этому известно, что большинство минеральных веществ (особенно неорганических солей, полученных методом химического синтеза), поступающих с кормом, не усваиваются и выводятся из организма, поскольку не были адсорбированы кишечником, следовательно, они не всосались в кровь и не включились в процесс обмена веществ [10].

В отличие от других минеральных добавок, цеолиты не набухают, не изменяют консистенцию корма и не препятствуют прохождению химуса по пищеварительному тракту. Все это способствует более полному перевариванию корма, повышению всасывания питательных и биологически активных его компонентов.

Использование современных технологий и достижений науки позволило приготовить новый продукт - модифицированный цеолит. Этот природный минерал уже без примесей и микробов, с открытыми окошечками пор, обладающий высокой способностью к селективному обмену, получен разными способами активации цеолита в промышленных условиях. При этом ульяновские специалисты освоили технологию обогащения полезными веществами модифицированного цеолита.

\section{Методика}

Целью нашей работы стало изучение влияния на организм индеек и уровень их продуктивности добавки на основе модифицированного цеолита, обогащенного аминокислотным комплексом «ВитаАмин». Эксперимент организован на 250 индейках породы Hybrid Creadmayker возраста 55-60 дней в условиях Ульяновской области в Сенгиевском районе в частном фермерском хозяйстве ИП «Чебулаев В.Е.».

Для эксперимента использовали кормовую добавку на основе модифицированного цеолита, обогащенного аминокислотами «ВитаАмин» для сельскохозяйственных птиц. В состав входит наполнитель - 97,09\% и концентрат аминокислот - 2,91\% (табл. 1). Действующими веществами являются - природный минерал цеолит, обработанный тремя способами активации, который является активным энтеросорбентом, ионообменником и катализатором, обладает свойством молекулярных сит, источник макро и микроэлементов. Вторым действующим веществом выступает аминокислотный комплекс «ВитаАмин», получен методом ферментативного гидролиза, имеют высокую биологическую активность. Модифицированный цеолит подвергается процессу 
обогащения (это не сумма компонентов, а распределение аминокислот в молекулярном сите цеолита) аминокислотным комплексом. Аминокислоты вступают с цеолитом в синергическое взаимодействие на ультрамолекулярном уровне, распределяясь в его молекулярном сите, поступая в организм в желудочно-кишечном тракте быстро всасываются и проявляют высокую биологическую активность.

Продолжительность опыта составила 60 дней. Сформировали две группы птиц по 125 голов в каждой. Первая контрольная группа получала основной рацион (ОР), заданный на птицеферме, второй группе дополнительно к ОР давали раз в сутки в утреннее кормление в смеси с комбикормом 5\% добавки модифицированного цеолита, обогащенного аминокислотами. ОР индеек 1-й группы состоял из следующих ингредиентов: пшеница - 60\%, ячмень $10 \%$, жмых (подсолнечник) - 15\%, соя (полножирная) - 5\%, шрот соевый - 5\%, масло растительное 3\% и витаминно-минеральный премикс «Биоэнергия» $-2,5 \%$. В целом был сбалансирован по основным питательным веществам, но имел недостаток по минеральным элементам. Для индеек 2-й группы использовали такой же ОР, только доля премикса «Биоэнергия» составила $1,2 \%$, при этом добавляли 5\% модифицированного и обогащенного аминокислотами цеолита (табл. 2).

В ходе опыта вели учет живой массы индеек методом контрольного взвешивания и по завершению провели убой по 5 птиц из каждой группы. Гематологические показатели определяли на анализаторе «PCE-90Vet», данные подвергали обработке с использованием программы Statistika.

\section{Результаты}

Изучение крови птиц позволяет охарактеризовать общее физиологическое состояние их организма, а также выявить скрытые нарушения обмена веществ, работы органов и иммунной системы.

Результаты опыта показали, что включение в рацион индеек добавки на основе модифицированного цеолита, обогащенного аминокислотами, не оказывает отрицательного влияния на гематологические параметры их крови, все показатели соответствовали физиологической норме. Напротив, отмечено улучшение морфологического состава крови у индеек опытной группы (табл. 3).

Таблица 1. Состав кормовой добавки

Table 1. Composition of the feed additive

Состав кормовой добавки

Цеолит модифицированный, кг

Концентрат аминокислот ВитаАмин, мл итого

\section{Таблица 2. Схема опыта}

Table 2. Experience diagram

Наименование

Условия кормления 1-я группа (контрольная) ОР + премикс «Биоэнергия» $-2,5 \%$

Таблица 3. Морфологический состав крови индеек

Table 3. Morphological composition of turkey blood

\begin{tabular}{|c|c|c|c|c|}
\hline Показатель, ед. & \multicolumn{3}{|c|}{ Группа } \\
\hline & $\begin{array}{c}\text { 1-я группа } \\
\text { (контроль) }\end{array}$ & $\%$ & $\begin{array}{c}\text { 2-я группа } \\
\text { (опыт) }\end{array}$ & $\begin{array}{c}\text { \% от кон- } \\
\text { троля }\end{array}$ \\
\hline Эритроциты, $10^{12} / л$ & $2,55 \pm 0,06$ & 100 & $2,76 \pm 0,10$ & 108,23 \\
\hline Лейкоциты, $10^{9} / л$ & $34,30 \pm 0,50$ & 100 & $19,40 \pm 0,31$ & 56,56 \\
\hline Гемоглобин, г/л & $104,00 \pm 3,00$ & 100 & $108,3 \pm 1,60$ & 104,13 \\
\hline Гематокрит, \% & $27,3 \pm 0,70$ & 100 & $28,6 \pm 1,12$ & 105,3 \\
\hline
\end{tabular}

Примечание: нормы у индеек содержания эритроцитов $-2,5-3,5 \cdot 10^{12} / л$, лейкоцитов $20-40 \cdot 10^{9} / л$, гемоглобина $-70-110$ г/л, гематокрита $-37-50 \%$

Таблица 4. Показатели продуктивности индеек

Table 4. Turkey productivity indicators

\begin{tabular}{|c|c|c|c|c|}
\hline \multirow{2}{*}{ Возраст индеек } & \multicolumn{4}{|c|}{ Живая масса, кг } \\
\hline \multirow{2}{*}{$\mathbf{5 5}$-60 суток } & $\mathbf{1 - я ~ г р у п п а ~ ( к о н т р о л ь ) ~}$ & \% & 2-я группа (опыт) & \% от контроля \\
\hline $110-115$ суток & $4,6 \pm 0,10$ & 100 & $4,58 \pm 0,08$ & 99,5 \\
\hline
\end{tabular}

Таблица 5. Показатели экономической эффективности

Table 5. Economic efficiency indicators

Показатель, ед.

Количество птиц в группе, гол.

Продолжительность опыта, дней

Получено в среднем мяса индейки (живым весом), кГ

Дополнительная прибыль, кг

Цена реализации мяса индейки, руб.

Получено в среднем мяса индейки (живым весом), руб.

Выручка, руб.

Себестоимость 1 кг индейки, руб.

Стоимость 1 кг кормовой добавки:

— «Биоэнергия», руб.

- обогащенный цеолит, руб.

Расход добавки, кг

— «Биоэнергия», руб

- обогащенный цеолит, руб.

Стоимость затрат на добавку, руб.

Условная прибыль, руб.

Дополнительная прибыль, руб.

Получено доп. прибыли на 1 руб. затрат, руб. 2-я группа (опытная)

$\mathrm{OP}+$ премикс «Биоэнергия» - 1,2\% + модифицированный цеолит, обогащенный аминокислотами - 5\% 
ется результатом взаимодействия регенеративных и дегенеративных процессов крови и кроветворных органов. Эритроциты индеек отличаются от эритроцитов млекопитающих, они имеют овальную форму и ядерные. Общий размер этих клеток колеблется от 6 до 13 мкм, физиологическая норма составляет 2,5-3,5·10 12 /л. Введение добавки в рацион индеек 2-й группы способствовало тенденции к увеличению числа эритроцитов в их крови до $2,76 \pm 0,1 \cdot 10^{12} / л$, что на 8,23\% больше, чем в 1-й группе.

Механизм окислительно-восстановительных процессов в организме птиц зависит от концентрации в крови гемоглобина. Уровень гемоглобина в крови птиц опытной группы соответствовал норме и достигал 108,3ะ1,6 г/л, что на 4,13\% выше, чем в контрольной группе.

Показатель гематокрита как в контрольной, так и в опытной группе был ниже нормативных значений (37$50 \%)$, что свидетельствует об анемии. Хотя применение добавки повысило значение этого показателя на 4,7\%

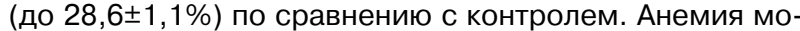
жет быть результатом хронических инфекционных заболеваний, пониженного образования эритроцитов или болезни печени.

Лейкоциты птиц несколько меньшего размера, чем у млекопитающих; участвуя в защитных реакциях в циркулирующей крови, они представляют собой группу разнообразных по форме и функциям белых клеток. Увеличение количества их - лейкоцитоз - указывает на развитие инфекций, воспаление, повреждение тканей или стрессовую реакцию. Снижение числа этих клеток является сигналом серьезной инфекции, отравления ядами и химикатами. Нами отмечено, что в крови индеек контрольной группы уровень лейкоцитов превысил норму и составил $34,3 \pm 4,5 \cdot 10^{9} / л$. А использование кремнийсодержащей добавки для птиц опытной группы способствовало нормализации этого параметра до $19,4 \pm 0,31 \cdot 10^{9} /$ л.

Положительное влияние скармливания добавки модифицированного цеолита на морфо-физиологические па-

\section{ЛИТЕРАTУPA/REFERENCES}

1. Гайнуллина М.К., Волков А.Х., Юсупова Г.Р., Якимов О.А., Дандрави М.К.А. Перспективы использования функциональных кормовых добавок в животноводстве и птицеводстве. В сборнике: Сельское хозяйство и продовольственная безопасность: технологии, инновации, рынки, кадры. Научные труды международной научно-практической конференции, посвященной 100-летию аграрной науки, образования и просвещения в Среднем Поволжье. 2019: 434-439. [Gaynulina M.K., Volkov A.X., Ysupova G.R., Yakimov O.A. Prospects for the use of functional feed additives in animal husbandry and poultry farming. In the collection: Agriculture and food security: technologies, innovations, markets, personnel. Scientific proceedings of the international scientific and practical conference dedicated to the 100th anniversary of agricultural science, education and enlightenment in the Middle Volga Region, 2019: 434-439 (In Russ.)].

2. Гайнуллина М.К. Диатомит - новая кормовая добавка для птицеводства. Аграрный вестник Урала. 2010:11-1(77): 30. [Gaynulina M.K. Diatomite is a new feed additive for poultry farming. Agrarian Bulletin of the Urals, 2010: 11-1(77): 30 (In Russ.)].

3. Фисинин В. Природные минералы в кормлении животных и птицы. Животноводство России, 2008;8: 66-68. [Fisinin V. Natural minerals in feeding animals and poultry. Animal Husbandry of Russia, 2008:8: 66-68 (In Russ.)].

4. Ахметова В.В., Мухитов А.З., Пульчеровская Л.П. Показатели тканевого метаболизма организма животных на фоне цитратцеолитовой добавки. Вестник Ульяновской государственной сельскохозяйственной академии. 2018;4(44): 118-122. [Akhmetova V.V., Mukhitov A.Z., Pulcherovskaya L.P., Indicators of the tissue metabolism of the animal body against the background of a citrateceolite supplement. Vestnik of Ulyanovsk state agricultural academy, 2018:4(44): 118-122 (In Russ.)].

5. Осинкина, Н.А., Кириллов Н.К., Алексеев Г.А. Применение цыплятам-бройлерам цеолитсодержащего трепела Яблоновского месторождения Чувашской Республики и его смеси с серосодержащими препаратами Ученые записки Казанской государственной академии ветеринарной медицины им. Н.Э. Баумана. 2012; 212: 105-108. [Osinkina N.A., Kirillov N.K., Alekseev G.A. Application to broiler chickens of zeolite-containing trepel from the Yablonovsky deposit of the Chuvash Republic and its mixture with sulfur-containing preparations. Scientific notes of the Kazan State Academy of Veterinary Medicine named after N.E. Bauman. 2012;212: 105-108 (In Russ.)].

6. Дежаткина С.В., Шаронина Н.В., Дежаткин М.Е. Влияние со- раметры крови индеек сказалось и на уровне их продуктивности. Рассматривали такие показатели, как живая масса и энергия роста. По данным контрольного взвешивания установлено, что у птиц 2-й группы происходит более интенсивное наращивание живой массы (табл. 4).

При постановке на опыт разница в живой массе у индеек в 1-й и 2-й группах была незначительной и состав-

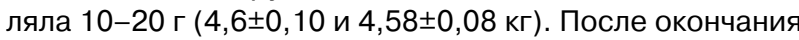
опыта живая масса индеек опытной группы превосходила контроль в среднем на 984 г, то есть была больше на $8,7 \%$. Об интенсивности роста молодняка подопытных птиц свидетельствует абсолютный прирост живой массы, который составил у птиц 2-й группы 125,5-128,6 против 110,5-111,0 г в контроле. Более точным показателем энергии роста служит относительный прирост. В группе с применением добавки этот показатель составил $140,29 \%$ против $84,36 \%$ в контроле, то есть больше на $55,93 \%$, косвенно указывая на стимуляцию анаболических процессов и образование тканевых белков в организме птиц, что возможно при повышении усвоения питательных веществ корма. Это подтверждается экономическими расчетами (табл. 5)

За время опыта (60 дней) во 2-й группе получено живым весом больше птицы на 8,70\%, что составило 12296 кг, соответственно больше получено прибыли при реализации мяса индейки, общая выручка составила 133210 , а дополнительная прибыль - 27960 рублей, за эксперимент на 1 рубль затрат получено 2,41 рубля прибыли.

\section{Выводы}

Поступление в организм индеек добавки на основе модифицированного цеолита, обогащенного аминокислотами, улучшает морфологический состав их крови и способствует увеличению интенсивности их роста и получению экономической прибыли. В целом данные указывают на нормализацию минерального гомеостаза в организме индеек и лучшее усвоение питательных веществ кормового рациона.

евой окары на морфо-биохимический статус организма кур-несушек. Материалы конференции: Аграрная наука и образование на современном этапе развития: опыт, проблемы и пути их решения. 2016; 119-125. [Dezhatkina S.V., Sharonina N.V., Dezhatkin M.E. The influence of soy okara on the morpho-biochemical status of the body of laying hens. Conference materials: Agricultural science and education at the present stage of development: experience, problems and ways to solve them. 2016: 119-125 (In Russ.)].

7. Халилов Э.Н., Багиров Р.А. Природные цеолиты, их свойства производство и применение. Международный союз научных исследований. Международная академия науки, здоровья и экологии, секция Азербайджан, Восточно-европейская секция, компания "Yeni Tech", Баку-Берлин, ISBN 5-8066-10006-4, 2002: 347. [Khalilov E. N., Bagirov R. A. Natural zeolites, their properties, production and application. International Union for Scientific Research. International Academy of Science, Health and Ecology, Azerbaijan Section, Eastern European Section, Yeni Tech Company, Baku-Berlin, ISBN 5-806610006-4, 2002: 347 (In End.)].

8. Hecht K. Heilung von Natur und Tierwelt durch die Anwendung des Naturzeoliths. Spurbuchverlag: Baunach. 2017: 162 p. (In End.)].

9. Lyubin N.A., Dezhatkina S.V., Akhmetova V.V., Muchitov A.Z. Dezhatkin M.E., Zyalalov S.R. Application of sedimentary zeolite in dairy cattle breeding. Russian Journal of Agricultural and Socio-Economic Sciences, 2020:1(97): 113-119 (In End.).

10.Дежаткина С.В., Зялалов Ш.Р., Дежаткин М.Е. Физиолого-биохимический статус коров при введении в их рацион кремнийсодержащей добавки. Вестник Ульяновской государственной сельскохозяйственной академии. 2021:1(53): 170-174. [Dezhatkina S.V., Syalalov Sch.R., Dezhatkin M.E.., Physiological and biochemical status of cows when a silicon-containing additive is introduced into their diet. Vestnik of Ulyanovsk state agricultural academy, 2021:1(53): 170 174 (In Russ.)]

11. Dezhatkina S.V., Nikitina I.A., Lyubin N.A., Dozorov A.V., Dezhatkin M.E., Mukhitov A.Z., Sharonina N.V., Akhmetova V.V. Use of nanostructured additive in turkey breding, Research Journal of Pharmaceutical, Biological and Chemical Sciences. 2019:10(3): 143148 (In End.)].

12.Vorotnikova I., Syalalov Sch.R., Dezhatkina S.V., Lyubin N.A. Biochemical status of Turkeys when fed with a complex nanoadditive. Bio web of conferences. International Scientific-Practical Conference "Agriculture and Food Security: Technology, Innovation, Markets, Human Resources" (FIES 2020), 2020: 00021(In End.). 